\title{
Direct observation and automated scoring of the activity of active and inactive
}

\section{inbred mouse strains}

\author{
CHARLES L. GOODRICK* \\ Gerontology Research Center \\ National Institute of Child Health and Human Development \\ Baltimore, Maryland 20014
}

Inbred mouse strains previously found to be low (A/J) and high (C57BL/6J) in open-field activity were tested in a plastic oval runway while their runway activity was directly observed and also monitored by a contact switch recording device. The activity of active $\mathrm{C} 57 \mathrm{BL} / 6 \mathrm{~J}$ mice was accurately monitored by the recording device, but scores of inactive $\mathrm{A} / \mathrm{J}$ mice were inflated by a factor between 2 and $3 \mathrm{X}$. Activity differences between strains were consistently maintained[during repeated tests under both high and very dim illumination if direct observational scores were used. Utilization of scores obtained by the automated recording device resulted in a failure to obtain group differences under the condition of dim illumination. These results were directly related to the mode of locomotion of the two mouse strains.

Strains of $\mathrm{A} / \mathrm{J}$ albino mice and C57BL/6J mice or closely related sublines have been utilized frequently in studies of the genetics of open-field activity. Although great differences in activity-level scores have been obtained by direct observational methods (McClearn, 1960; Fuller \& Thompson, 1960), other studies using automated tests have found relatively small mean activity differences between these strains (Bruell, 1964, 1967). Table 1 contrasts results from the four experiments. The present experiment was the result of an attempt to utilize automated test equipment for the study of exploration behavior of $A / J$ and C57BL/6J mouse strains and to determine directly the validity of the present automated test.

\section{Subjects}

\section{METHOD}

Male mice of the $A / J(N=16)$ and C57BL/6J $(N=16)$ strains were obtained from Jackson Memorial Laboratories (Bar Harbor, Maine) when 5 weeks old, and group caged (four per cage) in $10 \times 7$ in. cages with bedding changed weekly. Test animals from each strain were isolated in individual cages during the 6-day test interval when 5 months old. The mice were (1) on ad lib food and water, (2) on a cycle of 6 a.m. -6 p.m. light, 6 p.m.-6 a.m. dark, and (3) always picked up with forceps by the tail.

Apparatus and Procedure

Ss were individually tested in oval clear plastic runways on six

*Now at Gerontology Research Center, Baltimore City Hospitals. Baltimore, Maryland 21224. consecutive daily $20-\mathrm{min}$ sessions between 9 a.m. and 12 a.m. On the initial three sessions, light intensity was $15 \mathrm{fc}$, but on the last three sessions, testing was conducted in dim red illumination of about $0.1 \mathrm{fc}$. The continuous runway measured $18 \times 12$ in. o.d. and $12 \times 6$ in. i.d., so that the runway width was 3 in. Each mouse was placed in the runway at the narrow side of the oval, and the number of crossings of a point at the opposite side of the oval were tabulated visually for each 20-min trial. The runway was washed out and dried at the end of each test. An automated count of activity was obtained during each test by aluminum plates bolted to the floor, placed 1 in. apart at the same point in the field where the visual score was obtained, and connected to a reliable drinkometer circuit (Lehigh-Valley, Fogelsville, Pa.), which activated a pulse former, which in turn activated a counter.

\section{RESULTS}

Activity-White Light (Trials 1-3) Utilizing observational scores, we

Table 1

Mean Activity Scores of A and C57 Sublines Using Automated Test Scores (Auto) and Direct Observational Scores (Obs)

\begin{tabular}{lcc}
\hline & \multicolumn{2}{c}{ Strain } \\
\hline & A/J & C57BL/10 \\
Bruell, 1964 (Auto) & 129 & 151 \\
Bruell, 1967 (Auto) & 135 & 150 \\
& A/Crgl & C57BL/Crgl \\
McClearn, 1960 (Obs) & 10.2 & 200.8 \\
& A & C57BR \\
Fuller \& Thompson, & 11.0 & 532.0 \\
1960 (Obs) & & \\
\hline
\end{tabular}

showed that $\mathrm{C57 \textrm {BL } / 6 \mathrm { J }}$ strain mice were much more active than $A / J$ strain mice during all three test sessions $[F(1,30)=142.90, \quad p<.01]$. Mean scores are given in Table 2. Although strain differences decreased with trials [Strain by Trials, $F(2,60)=14.48$, $\mathrm{p}<.01]$, strain differences were still very large, with no overlap of scores.

When automated scores were analyzed, statistically significant strain differences were still obtained $[F(1,30)=42.95, \quad \mathrm{p}<.01]$, but activity differences between strains were reduced considerably, becaur scores of $\mathrm{C} 57 \mathrm{BL} / 6 \mathrm{~J}$ mice were si: ilar to those obtained by direct observation, while scores of $\mathrm{A} / \mathrm{J}$ mice were inflated 2 to 3 times (Table 2). The Strain by Trials interaction was also significant for these scores $[F(2,60)=13.51, p<.01]$

\section{Activity-Red Ligl.t (Trials 4-6)}

When tested under the condition of dim illumination, both strains increased direct observational scores relative to Trial 3 to about the same degree (Table 2). $\mathrm{A} / \mathrm{J}$ mice were inactive compared with C57BL/6J mice $[F(1,30)=48.76, p<.01]$, but strain differences were slightly less under these conditions. The Strain by Trials interaction was not statistically significant.

The automated test scores resulted in a failure to obtain significant strain differences in activity. $\mathbf{A} / \mathbf{J}$ mice had slightly higher scores than C57BL/6J mice for all three trials (Table 2).

\section{Correlations}

Significantly high correlations (all $<.01)$ were obtained between observational and automated counts of activity (Table 2 ).

\section{DISCUSSION}

The present mouse activity data indicate that direct observational test scores may yield greater between-strain differences than scores obtained by means of automated tests. The implications of these data for future behavioral genetics research using inbred mice are that the validity of an automated recording device must be obtained for each strain and group within strain tested.

When a relatively inactive $A / J$ mouse moves forward, there is a hesitancy of movement which may result in multiple counts for automated devices such as photocells, contact switches, or ultrasonic recorders. In contrast, the $\mathrm{C57 \textrm {BL } / 6 \mathrm { J }}$ mouse moves forward in a straightforward nonhesitant manner, so that extra counts are seldom elicited. Other mouse strains may have similar or more varied behavioral patterns, which will result in 
Table 2

Mean Activity Scores Utilizing Direct Observation (Obs) and Automated (Auto) Methods of Scoring and Spearman Rank Difference Correlations (tho) Between Obs and Auto Totals for Trials 1-3 and Trials 4-6

\begin{tabular}{|c|c|c|c|c|c|}
\hline & \multirow[b]{2}{*}{ Trial } & \multicolumn{2}{|c|}{$A / J$} & \multicolumn{2}{|c|}{ C57BL/6J } \\
\hline & & Obs & Auto & Obs & Auto \\
\hline \multirow[t]{2}{*}{$\begin{array}{l}\text { White } \\
\text { Light }\end{array}$} & $\begin{array}{l}1 \\
2 \\
3\end{array}$ & $\begin{array}{l}6.4 \\
8.0 \\
8.1\end{array}$ & $\begin{array}{l}13.5 \\
23.3 \\
18.9\end{array}$ & $\begin{array}{l}61.4 \\
39.7 \\
37.8\end{array}$ & $\begin{array}{l}66.6 \\
43.1 \\
40.4\end{array}$ \\
\hline & & \multicolumn{2}{|c|}{ rho $=.93$} & \multicolumn{2}{|c|}{ rho $=.91$} \\
\hline \multirow[t]{2}{*}{$\begin{array}{l}\text { Red } \\
\text { Light }\end{array}$} & $\begin{array}{l}4 \\
5 \\
6\end{array}$ & $\begin{array}{l}26.1 \\
24.8 \\
23.4\end{array}$ & $\begin{array}{l}58.9 \\
53.8 \\
63.4\end{array}$ & $\begin{array}{l}54.6 \\
49.4 \\
48.8\end{array}$ & $\begin{array}{l}\mathbf{5 8 . 3} \\
52.8 \\
52.3\end{array}$ \\
\hline & & \multicolumn{2}{|c|}{ rho $=.66$} & \multicolumn{2}{|c|}{ rho $=.96$} \\
\hline
\end{tabular}

automated scores which misrepresent their activity level.

Bolles and Sanders (1969) observed rats while their behavior was monitored by an ultrasonic activity recording device. Their results were that this recording device did measure activity, but that important changes in pattern of activity could not be differentiated. The present test also was highly correlated with direct observation scores of activity, but the total scores were dependent upon (1) mouse strain and (2) whether observational or automated scores were used. The only valid measure of mouse activity may be direct observation or some variant of time-lapse cinematography.

\section{REFERENCES}

BOLLES, R., \& SANDERS, G. What does the ultrasonic activity recording device measure? Behavior Research Methods \& Instrumentation, 1969, 1, 180-182.

BRUELL, J. Inheritance of behavioral and physiological characters of mice and the problem of heterosis. American Zoologist, 1964, 4, 125-138.

BRUELL, J. Behavioral heterosis. In J. Hirsch (Ed.), Behavior-genetic analysis. New York: McGraw-Hill, 1967. Pp. 270-286.

FULLER, J.. \& THOMPSON, R. Behavior genetics. New York: Wiley, 1960 Pp. 85-87.

MCCLEARN, G. Strain differences in activity of mice: Influence of illumination. Journal of Comparative \& Physiological Psychology, 1960, 53, $142-143$.

\section{ERRATUM}

MUNDL, WILLIAM J. A small pulse generator for calibrating EEG recording systems. Behav. Res. Meth. \& Instru., $1971,3,138-139$.-The citations for the two figures are reversed. 